\title{
Giant Joints in Association with Chronic Renal Failure
}

Nu Nu Win', Berrin Erok ${ }^{2 *}$

${ }^{1}$ Department of Radiology, Medicana Bahcelievler Hospital, İstanbul, Turkey.

${ }^{2}$ Universtiy of Health Sciences, Department of Radiology, Prof Dr Cemil Tascioglu City Hospital, İstanbul, Turkey.

*Corresponding Author: Berrin Erok, Universtiy of Health Sciences, Department of Radiology, Prof Dr Cemil Tascioglu City Hospital, İstanbul, Turkey.

Received date: January 22, 2021; Accepted date: March 08, 2021; Published date: March 11, 2021

Citation: Nu N Win, B Erok. (2021) Giant Joints in Association with Chronic Renal Failure. International Journal of Clinical Case Reports and Reviews. 6(4); DOI:10.31579/2690-4861/110

Copyright: () 2021 Berrin Erok, This is an open-access article distributed under the terms of the Creative Commons Attribution License, which permits unrestricted use, distribution, and reproduction in any medium, provided the original author and source are credited.

\begin{abstract}
Tumoral Calcinosis (TC) is an uncommon benign entitiy characterized by solitary or multiple tumorlike densely calcified periarticular masses located typically in the extensor surfaces of the large joints. TC can be primary or secondary. The primary TC is a rare hereditary familial disorder of phosphate regulation. On the other hand, secondary TC is associated with an underlying disease, most frequently, chronic renal faliure (CRF). Herein, we present a case of 40 year old male patient with CRF and 10 years history of hemodialysis, presenting with swellings around the right hip and left shoulder joints. The diagnosis of secondary TC has been made with typical computed tomography (CT) and magnetic resonance imaging (MRI) findings. Secondary TC is an uncommon condition particularly occuring in association with CRF. Typical radiologic findings and clinical history are leading in the diagnosis and prevent unnecessary further evaluations.
\end{abstract}

Key words: tumoral calcinosis; chronic renal failure; sedimentation sign

\section{Introduction}

Tumoral Calcinosis (TC) is an uncommon benign condition characterized by solitary or multiple tumorlike periarticular/juxtaarticular depositions of calcium. Presentation occurs with solitary or multiple swellings typically located in the extensor surfaces of the large joints like hip, shoulder and elbow with less common involvement of knee and small joints [1]. TC can be primary or secondary. The primary TC is a rare hereditary familial disorder presenting in the first or second decade of life and it is further subclassified as primary hyperphosphatemic TC and primary normophosphatemic TC according to the underlying metabolic dysfunction of phosphate regulation $[2,3]$. On the other hand, in secondary TC, there is an associated underlying disease causing multiple soft tissue calcifications, most frequently, chronic renal faliure (CRF) [3]. The underlying etiological mechanism for these massive periarticular calcifications in CRF is not clearly defined. Secondary hyperparathyroidism is suggested however, TC is also reported in the absence of secondary hyperparathyroidism [4]. Primary hyperparathyroidism, sarcoidosis, hypervitaminosis D and milk-alkali syndrome are among the other possible causes of secondary calcinosis [5]. We present a case of 40 year old male patient with CRF and 10 years history of hemodialysis presenting with secondary calcinosis of both hip and shoulder joints.

\section{Case Presentation}

A 40 year-old male patient with $\mathrm{CRF}$ who had been undergoing hemodialysis for 10 years had an abdominopelvic computed tomography (CT) scan 2 years before and a small soft tissue calcification was found incidentally around his right hip joint (fig.1), which growed up to $10 \mathrm{~cm}$ without pain within 2 years. At that time, the lesion was a multilobulated, cystic, amourphous, densely calcified mass with multiple scattered fluidfluid levels (fig. 2). There was no periosteal reaction or bony destruction. With history of CRF and typical CT features, the diagnosis of secondary TC was made. During this time another swelling around his left schoulder joint started to be grown up slowly without any symptom until the recently appeared pain which is aggrevated by movements of the joint. On magnetic resonance imaging [MRI], a periarticular soft tissue mass located in the subdeltoid bursa with the size of $14 \times 11 \times 8 \mathrm{~cm}$ was revealed. The lesion was heterogeneously hypointense on T1w and T2w images with scattered fluid-fluid levels (fig. 3). The adjacent bones had normal signal intensity but, prominent perilesional soft tissue edema was present, which is probably the cause of recently appeared pain in the slowly growing lesion. This second lesion was also diagnosed radiologically as secondary TC and confirmed by histopathological evaluation.

*Informed consent was taken from the patient. 


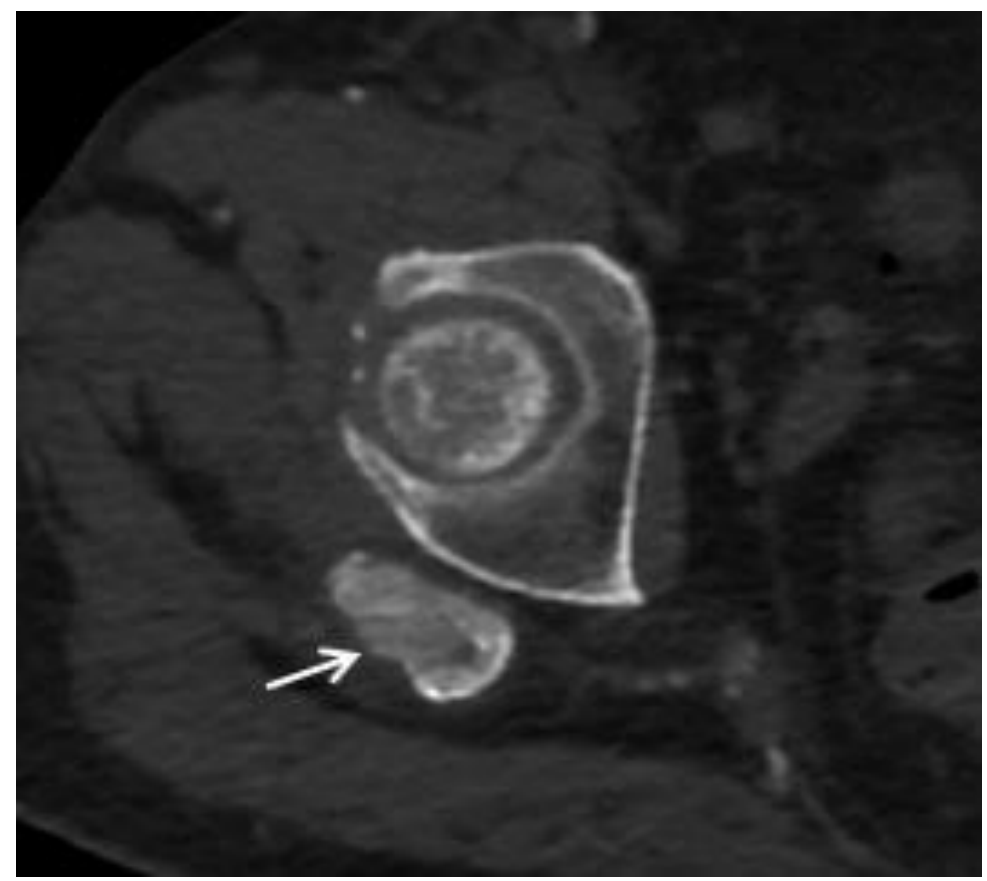

Figure 1: Axial CT image of the right hip demonstrating the incidentally found calcification (arrow) at the periarticular region.


Figure 2: axial (a) and coronal (b) CT images of the right hip joint after 3 years, demonstrate multilobulated, cystic and calcified soft tissue mass involving the right gluteus maximus and gluteus medius muscles. Fluid-calcium levels are shown (a, arrows). 


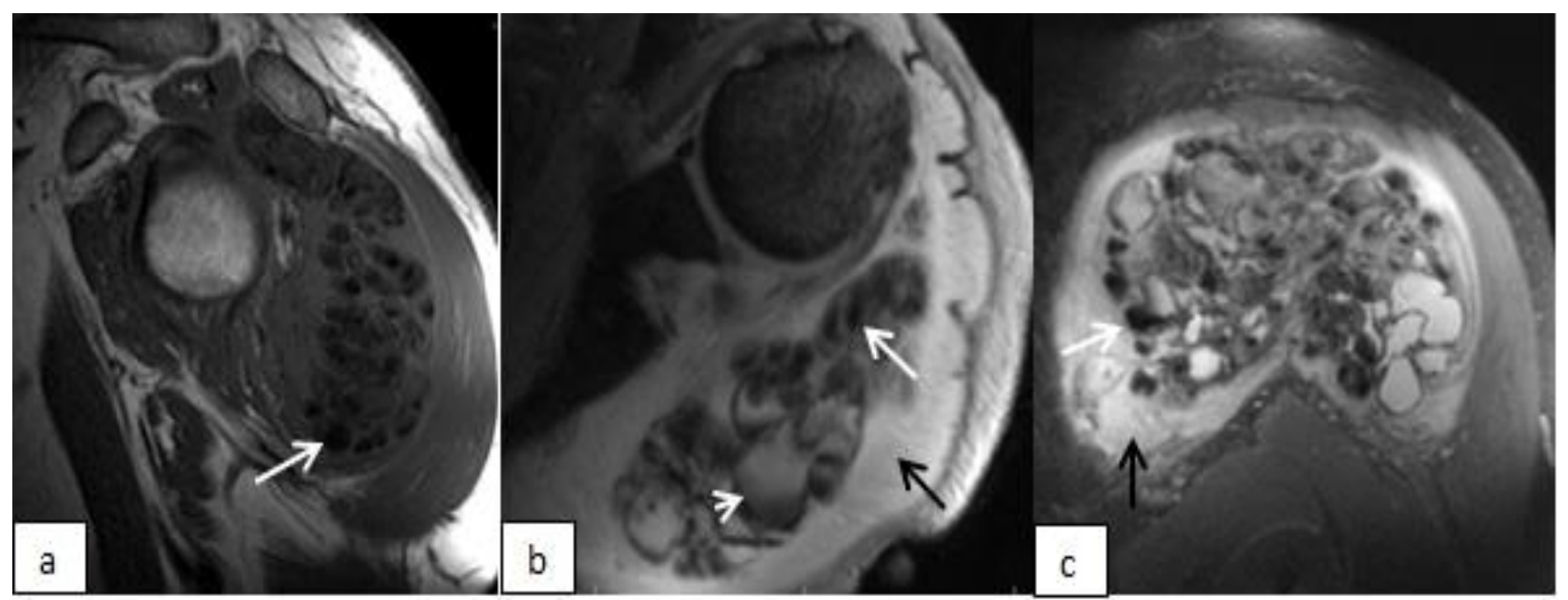

Figure 3: sagittal T1w (a), axial proton density (PD) (b) and coronal T2w fat-saturated (c) MRI images of the left shoulder showing a multilobulated inhomogenous lesion located in the subdeltoid bursa. On T1w image (a), the lesion is predominantly hypointense. On PD (b) and T2w (c) images, the lesion demonstrates bright, nodular pattern characterized with areas of high signal intensities and signal voids associated with clacifications (a,b,c; white arrows). The fluid-calcium level (b, short arrow) and perilesional edema (b,c; black arrow) are shown.

\section{Discussion}

Secondary TC is an uncommon complication observed in patients with $\mathrm{CRF}$, particularly in patients on hemodialysis with an incidence of $0.5 \%-$ $1.2 \%[4,6]$. TC has a cahracteristic appearance on radiological imaging studies. Radiography and CT scans show multilobulated, amorphous, cystic and calcified periarticular soft tissue masses typically located in a bursal distribution [3,7]. These cystic areas often demonstrate fluidcalcium levels on CT scans, which is caused by layering of milk of calcium and named also as sedimentation sign [8]. On MRI, TC show heterogeneous low signal intensity on T1w images. On T2w images, it may show low signal intensity pattern as would be expected from calcifications or may show bright, nodular pattern having heterogeneous areas of high signal intensity and signal voids. After IV gadolinium administration, some enhancement may be seen as a result of hypervascularity in the walls of the cystic areas [9]. In CRF patients, these masses typically grow slowly over months or years without pain, and may become symptomatic as a result of mass effect on adjacent tissues. Our case, presented with a recently appeared shoulder pain in the slowly growing lesion and perilesional edema/inflammation demonstrated on MRI, which is a very rare finding in association with TC. In the absence of bony destruction, the main differential diagnoses for soft tissue calcifications include metastatic calcifications which are associated with abnormal calcium and/or phosphate levels and dystrophic calcifications which are often secondary to trauma, underlying inflammatory processes like connective tissue diseases or atypical infections [3]. The big globs of calcifications near the joints in TC is differentiated from the metastatic and dystrophic calcifications which appear finely speckled calcifications throughout many other organs, such as kidneys, lungs, gastric mucosa, eyes, skin, vessels and also in joints. Although not expected from primary $\mathrm{TC}$, osseous destruction and/or intraosseous penetration is a rare but possible challenging feature in some cases of secondary TC in CRF patients reported in the literature. Steinbach et al. reported bony erosion along the humeral head and femoral neck in association with secondary calcinosis in CRF patients [10]. Girard et al. reported a case of secondary tumoral calcinosis with intraosseous penetration into the medullary space of the humerus [11]. The presence of osseous destruction poses a risk for pathological fractures and sometimes makes its differentiation from malignancy difficult. TC can show obvious FDG uptake on positron emission tomography which therefore is not useful for its differentiation from malignancy [12]. However, in secondary TC, clinical history, multifocality of the lesions, and also the absence of non-calsified components which are present in soft tissue sarcomas are generally helpful in differentiation from malignancy [13]. In equivocal cases, particularly in patients with solitary lesions with atypical findings like osseous destruction or perilesional edema, histopathological evaluation may be needed.

\section{Conclusion}

Secondary TC is an uncommon condition particularly occuring in association with CRF. Typical radiologic findings and clinical history are leading in the diagnosis and prevent unnecessary further evaluations. However, the presence of some atypical features, if present, can be challenging while making the diagnosis and histopathological evaluation may be needed in equivocal cases.

\section{References}

1. Chew FS, Bui-Mansfield LT, Kline MJ. (2003) Musculoskeletal Imaging. Lippincott, Williams \& Wilkins; Philadelphia, PA. 472473.

2. Maize J, Metcalf. (1997) Metabolic Diseases of the skin. In: Elder D (editor). Lever's Histopathology of the skin. 8th edn Philadelphia: Lippincott- Raven. 379-382.

3. Olsen KM, Chew FS. (2006) Tumoral calcinosis: pearls, polemics, and alternative possibilities. Radiographics. 26:871885.

4. Eisenberg B, Tzamaloukas AH, Hartshorne MR, Listrom MB, Arrington ER, Sherrard DJ. (1990) Periarticular tumoral calcinosis and hypercalcemia in a hemodialysis patient without hyperparathyroidism: a case report. J Nucl Med. 31:1099-1103.

5. Tchernin DA S, Lesage, A. et al (2013) Tumeurs des tissus mous. In: Masson E, (ed) Imagerie Musculosquelettique Pathologies générales, 2e ed Cotten A, Issy-les-Moulineaux. 530-597.

6. Franco M, Van Elslande L, Passeron C, et al. (1997) Tumoral calcinosis in hemodialysis patients: a review of three cases. Rev Rhum Engl Ed. 64:59-62. 
7. Fathi I, Sakr M. (2014) Review of tumoral calcinosis: a rare clinico-pathological entity. World J Clin Cases. 2:409-414.

8. HugI, Guncaga J. (1974) Tumoral calcinosis with sedimentation sign. Br J Radiol. 47:734-736.

9. Martinez S. (2002) Tumoral calcinosis: 12 years later. Semin Musculoskelet Radiol.;6:331-339.

10. Steinbach LS, Johnston JO, Tepper EF, Honda GD, Martel W. (1995) Tumoral calcinosis: radiologicpathologic correlation. Skeletal Radiol. 24(8):573-578.
11. Girard CJ, Wasserman PL, Lenchik L. (2009) Secondary Tumoral Calcinosis with Intraosseous Penetration. Radiology Case Reports.4:213.

12. Liu Y. (2016) Scintigraphic images of massive tumoral calcinosis. Clin Nucl Med.41:504-505.

13. Albergo JI, Gaston CL, Davies M, et al. (2013) Hoffa's fat pad tumours: what do we know about them? Int Orthop.37:2225-2229.
This work is licensed under Creative Commons Attribution 4.0 License

To Submit Your Article Click Here: Submit Manuscript

DOI: $10.31579 / 2690-4861 / 110$
Ready to submit your research? Choose Auctores and benefit from:

* fast, convenient online submission

* rigorous peer review by experienced research in your field

* rapid publication on acceptance

* authors retain copyrights

* unique DOI for all articles

* immediate, unrestricted online access

At Auctores, research is always in progress.

Learn more www.auctoresonline.org/journals/international-journal-ofclinical-case-reports-and-reviews 